\title{
IDENTIFIKASI MUTU NATA KULIT BUAH NAGA (Hylocereus undatus) DENGAN VARIASI KONSENTRASI SUKROSA
}

\section{QUALITY IDENTIFICATION OF DRAGON FRUIT PEEL (Hylocereus undatus) NATA WITH SUCROSE CONCENTRATION VARIATION}

\author{
Hesti Nur'aini, Eva Ramalia Sari \\ Program Studi Teknologi Pertanian, Fakultas Pertanian, Universitas Dehasen Bengkulu \\ Email : nayatha_hst@yahoo.co.id
}

\begin{abstract}
ABSTRAK
Sebagai hasil samping konsumsi buah naga, kulit buah naga masih mengandung komponen nutrisi yang berpotensi untuk dijadikan sebagai bahan baku pengolahan pangan, di antaranya nata kulit buah naga (Hylocereus undatus). Dalam pengolahan nata, penggunaan gula mutlak diperlukan sebagai sumber karbon untuk pertumbuhan bakteri A.xylinum. Tujuan penelitian ini adalah untuk mengkarakterisasi sifat fisik, kimia dan organoleptik nata kulit buah naga. Penelitian meliputi tahap pengolahan nata kulit buah naga dengan perlakuan konsentrasi sukrosa $(2 \%, 4 \%, 6 \%, 8 \%$ dan 10\%), kemudian dilakukan analisis fisik (tebal pelikel, berat pelikel dan tekstur), analisis sifat kimia (kadar serat) dan analisis uji organoleptik untuk mengetahui tingkat kesukaan terhadap kenampakan, rasa dan tekstur nata kulit buah naga, dengan menggunakan 20 orang panelis agak terlatih. Hasil analisis menunjukkan bahwa berat pelikel nata kulit buah naga berkisar antara $478 \mathrm{~g}$ s/d $752 \mathrm{~g}$, tebal pelikel berkisar 0,61 $\mathrm{cm} \mathrm{s} / \mathrm{d}$ 1,13 cm, kadar serat berkisar 3,63\% s/d 4,44\% dan tekstur berkisar 3,62 mm/g.detik $\mathrm{s} / \mathrm{d} 3,93 \mathrm{~mm} / \mathrm{g}$.detik dengan tingkat kesukaan panelis secara umum tidak berbeda nyata untuk semua parameter (kecuali pada perlakuan sukrosa 4\%) dengan skala penilaian antara agak suka sampai suka.
\end{abstract}

Kata kunci : Nata, sukrosa, kulit buah naga

\begin{abstract}
As a byproduct of the dragon fruit (Hylocereus undatus) consumption, dragon fruit peel still contains nutritional components that potential to be a material of food processing. In nata processing, sugar was used as a carbon source for Acetobacter xylinum bacterial growth. The purpose of this study was to characterize the physical, chemical and organoleptic nata of dragon fruit peel. The experiment was done with two steps : processing of nata of dragon fruit peel with sucrose treatment (2\%, $4 \%, 6 \%, 8 \%$ and $10 \%)$, then the physical analysis (thick pellicle, pellicle weight and texture), the analysis of chemical properties (fiber content) and analysis of organoleptic to determine the level of hedonic scale for appearance, taste and texture, using 20 trained panelists. The analysis showed that the pellicle weight ranges from $478 \mathrm{~g}-752 \mathrm{~g}$, thick pellicle ranges from $0.61 \mathrm{~cm}-1.13 \mathrm{~cm}$, the fiber content ranges from $3.63 \%-4.44 \%$ and textures ranges from $3.62 \mathrm{~mm} / \mathrm{g}$.second $-3.93 \mathrm{~mm} / \mathrm{g}$. second with panelists preference level generally not significantly different for all parameters (except the 4 $\%$ sucrose treatment) with the grading scale rather like until like.
\end{abstract}

Keywords : Nata, sucrose, dragon fruit peel 


\section{PENDAHULUAN}

Buah naga yang sering disebut dengan kaktus manis atau kaktus madu, adalah buah yang sekarang telah dikenal di Indonesia, bahkan mulai dikembangkan di tanah air serta memiliki peluang besar untuk disebarluaskan. Buah naga termasuk dalam keluarga tanaman kaktus dengan karakteristik memiliki duri pada setiap ruas batangnya. Konsumsi buah naga akan menghasilkan hasil samping kulit buah yang sampai sekarang belum dimanfaatkan secara optimal. Sementara beberapa uji laboratorium telah berhasil membuktikan bahwa kuit buah naga memiliki berbagai senyawa aktif seperti triyepene, pentacyclic dan taraxast. Senyawa-senyawa tersebut bermanfaat untuk melindungi kelenturan pembuluh darah. Selain itu, hasil penelitian lain juga membuktikan bahwa kulit buah naga dapat menekan pertumbuhan sel tumor b16f10. Riset Nurliyana R., dkk, menghasilkan data bahwa aktivitas dan kadar antioksidan dalam kulit buah naga merah dan kulit buah naga putih lebih besar dibandingkan dengan daging buahnya, dan bila dilihat dari kandungan fenolnya (TPC, Total Phenolic Content), daging buah naga merah (H. polyrhizus) mengandung antioksidan lebih tinggi daripada daging buah naga putih ( $H$. undatus). Selain itu, Sasina, S., (2012) dalam Jurnal of Food Research menyatakan kandungan total fenol dalam daging dan kulit buah naga merah yaitu sebesar 1.049,18 mgGAE/100g dan $561,76 \mathrm{mgGAE} / 100 \mathrm{~g}$ sedangkan total flavonoid sebesar 1310,10 mg CE/100g dan 220,28 mg CE/100g.

Melihat komposisi nilai gizi yang terkandung di dalamnya, kulit buah naga berpotensi untuk dijadikan sebagai bahan baku pengolahan pangan, di antaranya sirup kulit buah naga, selai kulit buah naga, manisan kulit buah naga dan nata kulit buah naga. Nata adalah biomassa yang sebagian besar terdiri dari sellulosa, berbentuk agar dan berwarna putih. Massa ini berasal dari pertumbuhan Acetobacter xylinum pada permukaan media cair yang asam dan mengandung gula. Nata dapat terbuat dari bahan baku air kelapa, dan limbah cair pengolahan tahu (whey tahu). Nata yang dibuat dari air kelapa disebut nata de coco dan dari whey tahu disebut nata de soya. Bentuk, warna, tekstur, dan rasa kedua jenis nata tersebut tidak jauh berbeda (Hasbullah, 2009). Nata merupakan suatu bahan makanan hasil fermentasi oleh bakteri Acetobacter xylinum yang kaya akan selulosa, bersifat kenyal, transparan, dan rasanya menyerupai kolang-kaling. Media fermentasi yang digunakan dalam pengolahan nata harus memenuhi kriteria sebagai sumber energi, pertumbuhan, motilitas dan biosintesa makro molekul. 
Oleh karenanya, medium yang digunakan harus mengandung komponen nutrien yang lengkap dan sesuai dengan kebutuhan mikroba yang menjalankan fermentasi (Lapus et eal, 1967). Pembuatan nata dalam ruang gelap akan mempercepat pembentukan struktur nata dan lapisan nata yang dihasilkan akan tebal (Luwiyanti (2001). Menurut Rahman (2004) sebagai starter dalam pembuatan nata, Acetobacter xylinum dapat tumbuh dan berkembang dalam medium gula dan akan mengubah senyawa gula menjadi selulosa (Budiyanto, 2004). Gula berfungsi sebagai sumber karbon (sumber energi). Sumber karbon bisa menggunakan glukosa, sukrosa maupun maltosa, namun biasanya industri pengolahan nata menggunakan sukrosa sebagai sumber karbonnya. Selain mudah diperoleh, harga sukrosa relatif lebih rendah dibandingkan jenis gula yang lain. Sukrosa merupakan faktor penting dalam proses fermentasi. Bakteri untuk menghasilkan nata membutuhkan sumber glukosa bagi proses metabolismenya. Glukosa akan masuk ke dalam sel yang dibutuhkan dalam perkembang biakannya. Jumlah glukosa yang ditambahkan harus diperhatikan sehingga mencukupi untuk metabolisme dan pembentukan pikel nata (Hidayat, 2006). Tanpa penambahan gula, tekstur nata menjadi kurang tebal. Sebaliknya, penambahan gula yang terlalu banyak (konsentrasi gula terlalu pekat) menyebabkan bakteri mengalami plasmolisis (kematian) (Warisno, 2004), yang akan menghambat aktivitas Acetobacter xylinum dalam membentuk selulosa (Nisa dkk, 2001).

Dari latar belakang di atas, penulis melihat bahwa kajian mengenai potensi kulit buah naga sebagai bahan baku pengolahan nata masih sangat minim, sehingga perlu dilakukan penelitian untuk mendapatkan teknologi pengolahan nata kulit buah naga khususnya mengenai penggunaan sukrosa yang tepat dalam pengolahan nata kulit buah naga tersebut. Tujuan penelitian ini adalah untuk mengkarakterisasi kualitas nata kulit buah naga dengtan perlakuan penambahan sukrosa, yang meliputi berat (gr), tebal $(\mathrm{cm})$, kadar serat $(\%)$, tekstur $(\mathrm{mm} / \mathrm{s})$ dan tingkat penerimaan panelis.

\section{METODE PENELITIAN}

\section{Bahan dan Alat Penelitian}

Bahan utama penelitian ini adalah kulit buah naga yang dibeli di Pasar Induk Panorama Kota Bengkulu. Bahan bantu untuk pengolahan nata terdiri dari inokulum/biakan Acetobacter xylinum, asam asetat, ZA 0,4 \% dan sukrosa. Peralatan yang digunakan meliputi panci, nampan plastik ukuran $35 \times 25 \times 4 \mathrm{~cm}$, gelas ukur, pH meter, timbangan, blender, saringan, kertas buram, karet pengikat, 
jangka sorong, penetrometer, kertas saring, desikator.

\section{Rancangan Percobaan}

Rancangan percobaan yang digunakan dalam penelitian ini adalah Rancangan Acak Lengkap (RAL) dengan 1 faktor (penambahan sukrosa), 5 perlakuan dan 3 kali ulangan. Perlakuan yang digunakan adalah penambahan sukrosa 4\% (S1), 6\% (S2), 8\% (S3), 10\% (S4) dan 12\% (S5). Data yang diperoleh dianalisis dengan menggunakan analisis sidik ragam dan jika terdapat perbedaan yang nyata antar perlakuan dilanjutkan dengan uji DMRT taraf $5 \%$.

\section{Pelaksanaan Penelitian}

Penelitian diawali dengan pengolahan nata kulit buah naga yang mengacu pada prosedur yang digunakan Warisno (2004), dengan tahapan sebagai berikut : sterilisasi sederhana terhadap alat dan nampan pencetak nata, kemudian dilanjutkan dengan pencucian, pemotongan dan penghancuran 300 gram kulit buah naga dalam 1 liter air. Setelah disaring, 1 liter ekstrak kulit buah naga direbus bersama sukrosa sesuai dengan perlakuan $(4 \%, 6 \%, 8 \%, 10 \%$ dan $12 \%), 5$ gram ZA $4 \%$ dan $20 \mathrm{~mL}$ asam asetat. Perebusan dilakukan selama 15 menit sambil diaduk-aduk. Dalam kondisi panas, adonan dituang ke dalam nampan plastik lalu ditutup dengan kertas buram dan diikat dengan karet pengikat, dan didiamkan selama 4 jam pada suhu ruang. Selanjutnya dilakukan penambahan 100 $\mathrm{mL}$ starter, ditutup kembali dan difermentasi selama 7 hari. Setelah 7 hari, nata dipanen, dicuci dan dibersihkan kemudian dianalisis tebal, berat pelikel, kadar serat, tekstur dan uji organoleptik dengan panelis agak terlatih sebanyak 20 orang.

\section{HASIL DAN PEMBAHASAN}

\section{Tebal Pelikel Nata Kulit Buah Naga}

Hasil pengukuran tebal pelikel nata kulit buah naga setelah fermentasi 7 hari dalam wadah nampan ukuran $35 \times 25 \times 4 \mathrm{~cm}$, disajikan pada Tabel 1 .

Hasil pengukuran menunjukkan bahwa semakin tinggi konsentrasi sukrosa yang diberikan, menghasilkan nata kulit buah naga yang secara signifikan berbeda. Dalam pembentukan pelikel nata, bakteri Acetobacter xylinum membutuhkan gula sebagai sumber karbon (C), yang bisa berasal dari glukosa, maltosa, laktosa, sukrosa, dekstrin atau galaktosa. Penelitian-penelitian sebelumnya melaporkan bahwa sumber $\mathrm{C}$ yang menunjang pertumbuhan optimal Acetobacter xylinum adalah glukosa dan sukrosa. Macam dan kadar gula yang ditambahkan dalam media fermentasi sangat mempengaruhi ketebalan dan berat 
nata yang terbentuk (Steinkraus, 1983; Gunzalus, 1972).

Pada penambahan sukrosa $4 \%$ dan $6 \%$ dihasilkan pelikel nata kulit buah naga yang lebh tipis dibandingkan dengan penambahan sukrosa $8 \%$, yang disebabkan sumber karbon dalam media fermentasi masih kurang sehingga selulosa yang disintesa bakteri Acetobacter xylinum juga sedikit. Pada penambahan sukrosa $10 \%$ dan $12 \%$ dihasilkan pelikel dengan ketebalan yang lebih tebal dari pada perlakuan lainnya, namun tidak berbeda nyata antara kedua perlakuan tersebut, sehingga secara ekonomis penambahan sukrosa $10 \%$ berada pada konsentrasi yang optimum.

\section{Berat Pelikel Nata Kulit Buah Naga}

Analisis berat pelikel nata kulit buah naga dilakukan dengan cara menimbang setiap cetakan nata yang terbentuk, berdasarkan masing-masing perlakuan. Hasil penimbangan pelikel nata kulit buah naga seperti terlihat pada Tabel 2, menunjukkan perbedaan yang nyata pada masing-masing perlakuan. Semakin tinggi kadar sukrosa yang ditambahkan, pelikel nata yang terbentuk semakin berat.

Sukrosa sebagai sumber karbon dalam media fermentasi Acetobacter xylinum memberikan peranan yang sangat penting dalam pembentukan pelikel nata. Penambahan gula yang kurang, akan menghasilkan nata yang kurang tebal dan berat karena sumber karbon untuk pembentukan selulosa kurang terpenuhi. Namun penggunaan sukrosa yang berlebihan juga akan menghasilkan nata yang kurang tebal dan berat, karena sumber karbon yang disintesa oleh bakteri Acetobacter xylinum sangat berlebih sehingga $\mathrm{CO}_{2}$ yang dihasilkan juga tinggi. Dalam media fermentasi, $\mathrm{CO}_{2}$ yang tinggi akan mempunyai daya tekan yang tinggi pula terhadap cairan fermentasi sehingga tekanan $\mathrm{CO}_{2}$ tersebut akan mengurangi rongga-rongga yang terdapat pada selulosa dan struktur selulosa akan merapat. Hal ini akan berakibat jumlah air yang terdapat pada selulosa sangat sedikit dan akan berpengaruh terhadap ketebalan dan berat pelikel (Pratiwi, 2002).

Pambayun (2002), mengungkapkan bahwa penambahan sukrosa yang berlebih dalam pembuatan nata dapat menyebabkan terganggunya aktivitas bakteri, mengakibatkan banyak sukrosa yang diubah menjadi asam, penurunan $\mathrm{pH}$ secara drastis dan merugikan industri nata. Selain itu, kelebihan sukrosa bisa menyebabkan browning, sehingga warna media menjadi gelap karena terperangkap dalam struktur serat nata yang transparan. 


\section{Tabel 1. Tebal Pelikel Nata Kulit Buah Naga}

\begin{tabular}{cc}
\hline Penambahan Sukrosa $(\%)$ & Tebal Pelikel (cm) \\
\hline 4 & $0,61^{\mathrm{d}}$ \\
6 & $0,71^{\mathrm{cd}}$ \\
8 & $0,83^{\mathrm{bc}}$ \\
10 & $0,93^{\mathrm{ab}}$ \\
12 & $1,13^{\mathrm{a}}$ \\
\hline
\end{tabular}

Ket : Hasil merupakan rerata tiga kali ulangan.

Notasi yang berbeda pada kolom yang sama menunjukkan beda nyata pada taraf signifikansi $5 \%$.

\section{Tabel 2. Berat Pelikel Nata Kulit Buah Naga}

\begin{tabular}{cc}
\hline Penambahan Sukrosa (\%) & Berat Pelikel (g) \\
\hline 4 & $478^{\mathrm{e}}$ \\
6 & $624^{\mathrm{d}}$ \\
8 & $625^{\mathrm{c}}$ \\
10 & $707^{\mathrm{b}}$ \\
12 & $752^{\mathrm{a}}$ \\
\hline
\end{tabular}

Ket: Hasil merupakan rerata tiga kali ulangan.

Notasi yang berbeda pada kolom yang sama menunjukkan beda nyata pada taraf signifikansi 5\%.

\section{Kadar Serat Nata Kulit Buah Naga}

Salah satu sumber gizi utama yang diharapkan dari konsumsi nata adalah kandungan seratnya yang tinggi. Definisi tentang serat makanan yang disampaikan oleh the American Association of Cereal Chemist (AACC, 2001) adalah bagian yang dapat dimakan dari tanaman atau karbohidrat analog yang resisten terhadap pencernaan dan absorpsi pada usus halus dengan fermentasi lengkap atau parsial pada usus besar. Lebih lanjut Kusharto (2006) menjelaskan bahwa nata sangat baik dikonsumsi terutama oleh mereka yang diet rendah kalori atau tinggi serat. Kandungan air yang tinggi berfungsi untuk memperlancar proses metabolisme tubuh. Serat nata di dalam tubuh manusia akan mengikat semua unsur sisa hasil pembakaran yang tidak diserap oleh tubuh, kemudian dibuang melalui anus berupa tinja atau bolus.

Hasil analisis kadar serat nata kulit buah seperti disajikan pada Tabel 3, menunjukkan bahwa semakin tinggi kadar sukrosa yang diberikan, menghasilkan kadar serat dalam nata yang semakin tinggi. Hal ini sejalan dengan pendapat 
Hasbullah (2009) yang menyatakan bahwa selain sebagai bahan pembentuk nata, sukrosa juga digunakan oleh Acetobcter xylinum sebagai sumber energi bagi aktivitasnya dan biosintesa produk pembentuk sel, sehingga berpengaruh nyata terhadap pembentukan selulosa.

Secara statistik, kadar serat nata kulit buah naga dengan penambahan sukrosa $4 \%$ sampai dengan $10 \%$ mengalami peningkatan secara nyata, namun pada perlakuan penambahan sukrosa $10 \%$ dan $12 \%$, tidak terjadi peningkatan kadar serat yang signifikan, sehingga secara ekonomis, penambahan sukrosa sebesar $10 \%$ adalah yang paling efektif.

Hasil penelitian menunjukkan bahwa kadar serat nata kulit buah naga berkisar antara 3,63\% hingga 4,44\%, hasil ini sudah sesuai dengan standar SNI 01-4317-
1996, yang mensyaratkan kadar serat dalam nata maksimal 4,5 \% (BSN, 1996).

\section{Uji Tekstur Nata Kulit Buah Naga}

Nata adalah makanan yang banyak mengandung serat yang tinggi sehingga menjadi salah satu makanan yang direkomendasikan sebagai makanan yang berfungsi untuk menjaga kesehatan pencernaan. Dari segi penampilan, nata memiliki nilai estetika yang tinggi, penampilan warna putih agak bening, tekstur kenyal dan aroma segar (Misgiyarta, 2007).

Hasil pengukuran tekstur nata kulit buah naga dengan variasi perlakuan sukrosa berkisar antara 3,62 - 3,93 mm/g.detik dan secara statistik, tidak ada perbedaan yang antar semua perlakuan yang diberikan.

Tabel 3. Kadar Serat Nata Kulit Buah Naga

\begin{tabular}{cc}
\hline Penambahan Sukrosa $(\%)$ & Kadar Serat $(\%)$ \\
\hline 4 & $3,63^{\mathrm{c}}$ \\
6 & $3,78^{\mathrm{b}}$ \\
8 & $3,83^{\mathrm{b}}$ \\
10 & $4,14^{\mathrm{a}}$ \\
12 & $4,44^{\mathrm{a}}$ \\
\hline
\end{tabular}

Ket : Hasil merupakan rerata tiga kali ulangan. Notasi yang berbeda pada kolom yang sama menunjukkan beda nyata pada taraf signifikansi $5 \%$. 
Tabel 4. Hasil Pengukuran Tekstur Nata Kulit Buah Naga

\begin{tabular}{cc}
\hline Penambahan Sukrosa (\%) & Tekstur (mm/g.detik) \\
\hline 4 & $3,62^{\mathrm{ab}}$ \\
6 & $3,60^{\mathrm{b}}$ \\
8 & $3,67^{\mathrm{ab}}$ \\
10 & $3,73^{\mathrm{ab}}$ \\
12 & $3,93^{\mathrm{a}}$
\end{tabular}

Ket : Hasil merupakan rerata tiga kali ulangan. Notasi yang berbeda pada kolom yang sama menunjukkan beda nyata pada taraf signifikansi $5 \%$.

\section{Sifat Organoleptik Nata Kulit Buah Naga}

Analisis uji organoleptik dilakukan terhadap minuman nata kulit buah naga, untuk mengetahui tingkat kesukaan 20 orang panelis agak terlatih terhadap parameter warna, rasa dan tekstur. Hasil pengujian disajikan pada Tabel 5.

Hasil uji organoleptik nata kulit buah naga menunjukkan bahwa tingkat kesekaan panelis terhadap nata kulit buah naga berdasarkan parameter warna, rasa dan tekstur secara umum tidak berbeda nyata, kecuali pada perlakuan penambahan sukrosa $4 \%$, dengan skala penilaian antara agak suka sampai suka. Dengan kata lain, produk nata kulit buah naga secara organoleptik bisa diterima oleh konsumen. Selain memiliki nilai estetika yang tinggi, penampilan warna putih agak bening, tekstur kenyal dan aroma segar, nata juga memiliki kadar serat yang tinggi sehingga bisa memelihara kesehatan penecernaan.

Tabel 5. Sifat Organoleptik Nata Kulit Buah Naga

\begin{tabular}{cccc}
\hline Penambahan Sukrosa (\%) & Warna & Rasa & Tekstur \\
\hline 4 & $3,30^{\mathrm{a}}$ & $2,70^{\mathrm{b}}$ & $3,20^{\mathrm{b}}$ \\
6 & $3,30^{\mathrm{a}}$ & $3,60^{\mathrm{a}}$ & $3,55^{\mathrm{ab}}$ \\
8 & $3,15^{\mathrm{a}}$ & $3,65^{\mathrm{a}}$ & $3,75^{\mathrm{a}}$ \\
10 & $3,35^{\mathrm{a}}$ & $3,60^{\mathrm{a}}$ & $3,80^{\mathrm{a}}$ \\
12 & $3,30^{\mathrm{a}}$ & $3,90^{\mathrm{a}}$ & $3,90^{\mathrm{a}}$ \\
\hline
\end{tabular}

Ket Skala : $5=$ sangat suka; $4=$ suka; $3=$ agak suka; $2=$ tidak suka; $1=$ sangat tidak suka Notasi yang berbeda pada kolom yang sama menunjukkan beda nyata dengan taraf $5 \%$ 


\section{KESIMPULAN}

Dari hasil penelitian, bisa disimpulkan bahwa kulit buah naga mempunyai potensi yang tinggi untuk diolah menjadi produk nata, dengan klasifikasi mutu berat pelikel nata kulit buah naga berkisar antara $478 \mathrm{~g}$ s/d $752 \mathrm{~g}$, tebal pelikel berkisar $0,61 \mathrm{~cm} \mathrm{~s} / \mathrm{d} 1,13 \mathrm{~cm}$, kadar serat berkisar 3,63\% s/d 4,44\% dan tekstur berkisar 3,62 $\mathrm{mm} / \mathrm{g}$.detik $\mathrm{s} / \mathrm{d} \quad 3,93$ mm/g.detik. Hasil uji sensoris menunjukkan bahwa secara umum tidak berbeda nyata untuk semua parameter (kecuali pada perlakuan sukrosa 4\%) dengan skala penilaian antara agak suka sampai suka.

\section{DAFTAR PUSTAKA}

AACC. (2001). The Definition of Dietary Fiber. American Association of Cereal Chemists. Vol. 46 No.3.

Badan Standarisasi Nasional. (1996). SNI 01-4317-1996. Nata dalam Kemasan. Departemen Perindustrian. Jakarta.

Gunzalus. (1972). Factor Affecting Production of Cellulose at The Air / Liquid Interface of Culture of Acetobacter xylinum. Journal of General Microbiology. 11 : $123-129$.

Hasbullah. (2009). Nata de Soya. Teknologi Tepat Guna Agroindustri Kecil. Sumatera Barat.

Hidayat. (2006). Mikrobiologi Industri. Andi Offset. Yogyakarta.

Kusharto, C. (2006). Serat Makanan dan Peranannya bagi Kesehatan.
Jurnal Gizi dan Pangan I (2) : 45 $-54$.

Lapuz, M.M., E.G Gallardo., M.A Palo. (1967). The Nata Organism Cultural. Requirement Characteristic and Identity. The Philipines Journal of Science. 96 (2) : 91 - 109.

Luwiyanti, H. (2001). Pengaruh Penggunaan Sumber Nitrogen pada Medium Filtrat Kulit Buah Pisang Kepok terhadap Berat, Tebal dan Sifat Organoleptik Nata. Skripsi Program S1 Teknologi Hasil Pertanian. Fakultas Teknologi Pertanian Universitas Semarang.

Misgiyarta. (2007). Teknologi Pembuatan Nata de Coco. Balai Besar Penelitian dan Pengembangan Pascapanen Pertanian. Bogor

Nisa, F.C., R.H. Hani., T. Wastono., B. Baskoro dan Moestijanto. (2001). Produksi Nata dari Limbah Cair Tahu (Whey) : Kajian Penambahan Sukrosa dan Ekstrak Kecambah. Jurnal Teknologi Pertanian. $2: 74-78$.

Pambayun, R.(2013). Teknologi Pengolahan Nata de Coco. Penerbit Kanisius. Yogyakarta.

Pratiwi,E. (2002). Karakteristik Nata dari Pulp Kakao Mulia (Theobroma cacao. L) dengan Penambahan Berbagai Konsentrasi Sukrosa. Jurnal Tekologi Pangan dan Hasil Pertanian. 5 (2) : 81 - 85.

Rahman. 2004. Pengantar Teknologi Fermentasi. Arcan. Jakarta.Budiyanto, 2004.

Sasina Sangthawan. (2012). Prebiotic Activity and Bioactive Compounds of The Enzymatically Depolymerized Thailand-Grown Mangosteen Aril. Journal of Food Research . I (I).

Steinkraus. (1983). Handbook of Indigenous Fermented Food. Marcel Dekker Inc. New York. 
Warisno. (2004). Mudah dan Praktis

I. Agromedia Pustaka. Jakarta. Membuat Nata de Coco. Cetakan 